\title{
Spatial and temporal analysis of the risks posed by metal contamination in coastal and marine sediments of Bahrain
}

\author{
E. E. M. Nicolaus $(\mathbb{D} \cdot$ D. L. Maxwell • \\ A. S. Khamis · K. H. Abdulla • R. P. Harrod • \\ M. J. Devlin • B. P. Lyons
}

Received: 16 July 2021 / Accepted: 23 December 2021 / Published online: 6 January 2022

(c) Crown 2022

\begin{abstract}
Nine metals including $\mathrm{Al}, \mathrm{Cd}, \mathrm{Cr}, \mathrm{Cu}$, $\mathrm{Fe}, \mathrm{Mn}, \mathrm{Ni}, \mathrm{Pb}$ and $\mathrm{Zn}$ were analysed from sediment samples collected from 29 stations since 2007 from Bahraini waters. Within this study, it was investigated whether concentrations of these determinants are at concentrations above internationally established Assessment Criteria (AC). The majority of sites were considered not to pose a toxicological risk in terms of metal contamination. Where breaches occurred, they were mainly from historic samples related to $\mathrm{Cr}, \mathrm{Cu}$ and $\mathrm{Ni}$ contamination. A trend assessment revealed that out of 59 significant trends, 36 were downwards
\end{abstract}

Supplementary information The online version contains supplementary material available at https://doi. org/10.1007/s10661-021-09722-7.

E. E. M. Nicolaus $(\bowtie) \cdot$ D. L. Maxwell · R. P. Harrod ·

M. J. Devlin

Cefas, Lowestoft Laboratory, Pakefield Road,

Lowestoft NR33 OHT, UK

e-mail: manuel.nicolaus@cefas.co.uk

A. S. Khamis - K. H. Abdulla

Supreme Council for Environment, P.O. Box 18233,

Manama, Bahrain

B. P. Lyons

Centre for Environment, Fisheries and Aquaculture

Science (Cefas), Weymouth laboratory, Barrack Road,

Weymouth DT4 8UB, Dorset, UK

B. P. Lyons

British Embassy at the State of Kuwait, P.O. Box 2,

13001 Safat, Kuwait and 23 upwards, indicating that some determinants like $\mathrm{Al}, \mathrm{Zn}$ and $\mathrm{Ni}$ are improving strongly across some sites, whilst areas associated with industrial activity still see some increasing trends for $\mathrm{Al}, \mathrm{Cd}, \mathrm{Pb}$ and $\mathrm{Zn}$.

Keywords Metals $\cdot$ Marine sediments $\cdot$ Risk characterisation ratio $\cdot$ Environmental quality standards (OSPAR BAC, ERL, ERM, ISQG, PEL) . Status and trend assessment $\cdot$ Bahrain

\section{Introduction}

The Kingdom of Bahrain, located in the south-western Arabian Gulf (Fig. 1), has undergone major economic, social and industrial development since the 1970s (Elghonaimy \& Mohammed, 2019; Naser, 2015). Bahrain's population increased tenfold between 1959 and 2018 (Information \& eGovernment Authority, 2021). This rapid expansion of Bahrain's urban and industrial sectors has mainly occurred around its coasts, making it one of the most densely populated countries in the world (Zainal et al., 2009; Information and eGovernment Authority, 2021). To meet the land requirements for this population and economic growth Bahrain has now developed more than $80 \%$ of its coastline and reclaimed an additional $110 \mathrm{~km}^{2}$ of its coastal waters (Naser, 2015). However, this economic and social development has put ecologically important marine ecosystems, including sea grass beds, coral reefs and 


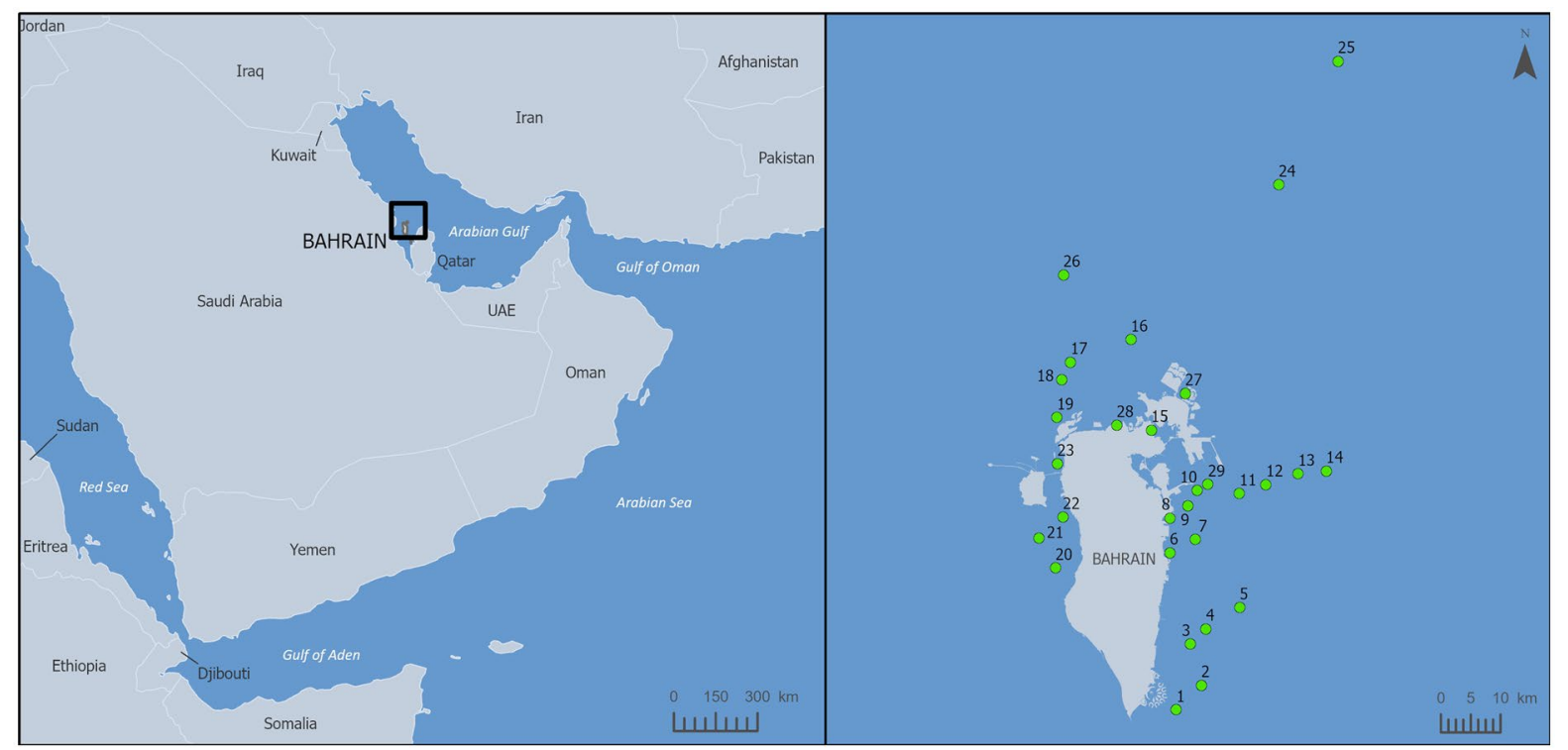

Fig. 1 A pool of 29 sediment sampling stations around Bahrain

mangroves under pressure (Abido et al., 2011; Burt et al., 2013; Naser, 2015).

This coastal development, which includes petrochemical, power generation and desalination industries, discharges significant volumes of effluent into Bahrain's marine waters. Consequently, a variety of contaminants have been reported in biota, sediment and water samples, including petroleum hydrocarbons, organohalogens, metals and nutrients from sewage treatment plants (Bersuder et al., 2020; de Mora et al., 2010; Naser, 2011; Tolosa et al., 2005). These contaminant inputs pose a risk to Bahrain's marine habitats, which serve as a feeding and nursery ground for many ecologically and economically important species like dugongs and green turtles (Abdulqader, 1999; Zainal et al., 2007; Moore \& Peirce, 2013; Arab Regional Centre for World Heritage \& Supreme Council for Environment, 2017).

The Public Commission for the Protection of Marine Resources, Environment and Wildlife (PMEW) of Bahrain initiated a marine monitoring program in 2007 by investigating the contaminant loads in sediments to see if they pose any threat to the marine environment. This was continued from 2012 onwards by the Supreme Council for the Environment (SCE) (Abdulla \& Naser, 2021). Monitoring focused on priority metal contaminants including those such as cadmium $(\mathrm{Cd})$ and lead $(\mathrm{Pb})$ that are known to have effects to marine organisms.
Cd for example tends to accumulate in the food chain as it is being actively taken up by algae and animals in parallel with phosphate (Nicolaus et al., 2018). Whilst $\mathrm{Pb}$ does not bioaccumulate, it still cause adverse effects to marine life and has been added to the OSPAR priority hazardous substance list (Nicolaus et al., 2018).

In this paper, the metal data collected between 2007 and 2020 from up to 29 sediment stations have been analysed for status and trend assessment by comparing the measured values to internationally derived Assessment Criteria (AC).

\section{Materials and methods}

Sediment monitoring started in 2007 at 20 stations and increased to a network of 29 stations by 2020 (Fig. 1; Table 1). Not every station was sampled every year, but a core of 10 stations were sampled each year between 2007 and 2020. As depicted in Fig. 1, the stations are located around the coastline apart from the south western side, where no stations are sited. The main historic reason for this was that the south west was seen not within an industrial area and ecologically less significant compared to the eastern and northern coasts which contain important habitats such as coral and sea grass beds, along with the concentration of coastal development (both urban and industrial). 
Table 1 A pool of 29 sediment sampling stations around Bahrain and their coordinates

\begin{tabular}{|c|c|c|c|}
\hline Station name & $\begin{array}{l}\text { Station } \\
\text { number }\end{array}$ & $\begin{array}{l}\text { Latitude } \\
\text { (decimal } \\
\text { degrees) }\end{array}$ & $\begin{array}{l}\text { Longitude } \\
\text { (decimal } \\
\text { degrees) }\end{array}$ \\
\hline Noon & 1 & 25.8137 & 50.64265 \\
\hline Mashtan & 2 & 25.8512 & 50.68428 \\
\hline Jabari & 3 & 25.91343 & 50.66568 \\
\hline Tugailib & 4 & 25.93642 & 50.69192 \\
\hline Ghumais & 5 & 25.96878 & 50.74847 \\
\hline Askar & 6 & 26.05145 & 50.63127 \\
\hline Msoor & 7 & 26.07212 & 50.67415 \\
\hline Refinery Area & 8 & 26.10388 & 50.63132 \\
\hline Gaha & 9 & 26.12193 & 50.6612 \\
\hline Suhain & 10 & 26.14552 & 50.67635 \\
\hline Duwaimil & 11 & 26.14113 & 50.74765 \\
\hline Gazara & 12 & 26.15477 & 50.7923 \\
\hline Dam & 13 & 26.17135 & 50.84602 \\
\hline Jaradah & 14 & 26.17547 & 50.89312 \\
\hline Jetty 1 & 15 & 26.23675 & 50.59925 \\
\hline Al-Jarim & 16 & 26.37308 & 50.56458 \\
\hline Khorfasht & 17 & 26.33843 & 50.46312 \\
\hline Murwada & 18 & 26.31138 & 50.44875 \\
\hline Bartafi & 19 & 26.25533 & 50.44062 \\
\hline Gasar & 20 & 26.02772 & 50.43943 \\
\hline Umm Al-Na'asan & 21 & 26.07283 & 50.41108 \\
\hline Ya'suf & 22 & 26.10483 & 50.45145 \\
\hline Al-Jasra & 23 & 26.18522 & 50.44183 \\
\hline Shtaya & 24 & 26.60762 & 50.81273 \\
\hline Bulthama & 25 & 26.79462 & 50.91242 \\
\hline West Jarim & 26 & 26.47017 & 50.4505 \\
\hline Jetty 2 & 27 & 26.29179 & 50.6560 \\
\hline Jetty 3 & 28 & 26.24393 & 50.54117 \\
\hline Wharf Area & 29 & 26.15477 & 50.6947 \\
\hline
\end{tabular}

The start and end years of sampling were not included in here because they are dependent on the determinant and this information can be found in Tables S5 and S6

Overall, the monitored stations include important fishing grounds, oyster beds, marine protected areas and anthropogenically impacted areas.

For the collection of sediments, a hand-held Van Veen grab was deployed from the boat. The top layer $(1-5 \mathrm{~cm})$ of each grab sample was collected using a wooden scoop and immediately transferred to an acid rinsed 500-mL glass jar. At some stations where the sediment was coarse sand, the whole sample was retained. Samples were kept in an icebox then stored in a freezer at $-20{ }^{\circ} \mathrm{C}$ upon arrival to the laboratory. These samples were then analysed in a chemical analytical lab for the metals aluminium (Al), Cd, chromium $(\mathrm{Cr})$, copper $(\mathrm{Cu})$, iron $(\mathrm{Fe})$, manganese $(\mathrm{Mn})$, nickel ( $\mathrm{Ni}), \mathrm{Pb}$ and zinc $(\mathrm{Zn})$.

Samples were dried using a freeze dryer (LABCONCO FreeZone 4.5) and sieved. The finest fraction $(<63 \mu \mathrm{m})$ was transferred to small glass vials for metal analysis. Before acid digestion, vials were shaken manually for 2 min to homogenise samples. Triplicates of around $0.1-0.3 \mathrm{~g}$ of each sample were placed in a Teflon bomb. Then, $5 \mathrm{~mL}$ of concentrated nitric acid $\left(\mathrm{HNO}_{3}\right)$ and $2 \mathrm{~mL}$ of hydrofluoric acid (HF) were added. The Teflon bombs were kept at room temperature for $1 \mathrm{~h}$; then, they were closed tightly and placed in a Microwave Digestion System (MILESTONE model, ETHOS PLUS). Samples were fully digested by applying the digestion routine illustrated in Table S1. When digestion was complete, samples were left to cool down to room temperature and transferred quantitatively to $50-\mathrm{mL}$ polypropylene graduated tubes containing $0.8 \mathrm{~g}$ of boric acid ( $0.4 \mathrm{~g}$ of $\mathrm{H}_{3} \mathrm{BO}_{3}$ for every $1 \mathrm{~mL}$ of $\mathrm{HF}$ ) and made up to $50 \mathrm{~mL}$ with deionised water. Digested samples were placed in an ultrasonic bath for $30 \mathrm{~min}$ to facilitate dissolution of boric acid.

To ensure quality control, one blank was run along with samples in each digestion batch (1 blank and 11 samples in each batch). Certified reference materials (CRMs) were also digested in triplicates and treated similarly. CRMs used were IAEA-405 (estuarine sediment), IAEA-433 (marine sediment) and IAEA356 (polluted marine sediment). The adequacy of the CRMs and batch analysis can be seen in Table S2. Concentration of heavy metals in samples, blanks and CRMs were determined using Atomic Absorption Spectroscopy (AAS). Two different instruments were used: Thermo model, M6 SERIES during the period 2007-2018 and Thermo model, iCE 3000 SERIES during the period 2019-2020. Techniques and gases used are illustrated in Table S2. For calibration, a series of standards were prepared by diluting 1000-ppm stock standards. Calibration curves were constructed by at least 3 points along with the blank (zero) and had a fit of at least 0.995 .

The raw data were then analysed for status and trend. A spatial status assessment was carried out by comparing AC (Table 2) to sampled metal concentrations in sediment to investigate if these concentrations 
Table 2 Internationally agreed assessment criteria formetals

\begin{tabular}{lcccccc}
\hline Metal & $\begin{array}{c}\text { Contaminant } \\
\text { symbol }\end{array}$ & $\begin{array}{c}\text { OSPAR BAC } \\
\left(\mathrm{mg} \mathrm{kg}^{-1}\right)\end{array}$ & $\begin{array}{c}\text { ERL } \\
\left(\mathrm{mg} \mathrm{kg}^{-1}\right)\end{array}$ & $\begin{array}{c}\text { ERM } \\
\left(\mathrm{mg} \mathrm{kg}^{-1}\right)\end{array}$ & $\begin{array}{c}\text { ISQG } \\
\left(\mathrm{mg} \mathrm{kg}^{-1}\right)\end{array}$ & $\begin{array}{c}\text { PEL } \\
\left(\mathrm{mg} \mathrm{kg}^{-1}\right)\end{array}$ \\
\hline Cadmium & $\mathrm{Cd}$ & 0.31 & 1.2 & 9.6 & 0.7 & 4.2 \\
Chromium & $\mathrm{Cr}$ & 81 & 81 & 370 & 52.3 & 160 \\
Copper & $\mathrm{Cu}$ & 27 & 34 & 270 & 18.7 & 108 \\
Nickel & $\mathrm{Ni}$ & 36 & 20.9 & 51.6 & $\mathrm{NA}$ & $\mathrm{NA}$ \\
Lead & $\mathrm{Pb}$ & 38 & 46.7 & 218 & 30.2 & 112 \\
Zinc & $\mathrm{Zn}$ & 122 & 150 & 410 & 124 & 271 \\
\hline lowest assessment criteria & & & & & \\
$2^{\text {nd }}$ lowest assessment criteria & & & & & \\
$3^{\text {rd }}$ lowest assessment criteria & & & & & \\
$2^{\text {nd }}$ highest assessment criteria \\
highest assessment criteria
\end{tabular}

could have any impacts on marine life in a specific area.

Bahrain does not yet have formally adopted sediment quality guidelines (SQGs) (Abdulla \& Naser, 2021), so the available data were assessed against a range of internationally adopted AC (Table 2). The AC used in this manuscript were recently described by Bersuder et al. (2020), which include OSPAR Background Assessment Concentrations (BACs; OSPAR, 2008), United States Environmental Protection Agency Effects Range Low (US EPA ERL; Long \& MacDonald, 1998), US EPA Effects Range Median (ERM; Long \& MacDonald, 1998), Canadian Interim Sediment Quality Guidelines (ISQG; Canadian Council of Ministers of the Environment, 2001) and Probable Effect Levels (PEL; Canadian Council of Ministers of the Environment, 2001). Generally, OSPAR BACs are said to be 'near-background' (based on samples collected from the North-East Atlantic region) and concentrations below this AC do not pose harm to the marine environment. The US and Canadian quality standards work in a similar way. Concentrations above the ERL or ISQG indicate that small effects may occur to organisms living in or near the assessed sediments, whilst concentrations above the ERM or PEL suggest that some effects are likely to occur to bottom-dwelling organisms (Bersuder et al., 2020; Nicolaus et al., 2015). These standards were established for European and American sediment backgrounds and should be adopted with care, as some baseline metal concentrations observed in the Arabian Gulf region are above various sediment quality guidelines (SQGs; Al-Sarawi et al., 2015; Alshemmari et al., 2010; Bersuder et al., 2020; Lyons et al., 2015). Al-Abdali et al. (1996) proposed metal background concentration for the Arabian Gulf region (Table 2) which was taken into consideration in the discussion. Metal data within the OSPAR region are also normally normalised against 5\% Al apart from Spain, where the background concentrations are not as homogenous compared to the other OSPAR regions (OSPAR, 2009). The same approach was taken within this study. The $\mathrm{Al}$ mean concentrations around Bahrain $\left(6521.4 \mathrm{mg} \mathrm{kg}^{-1}\right.$ or $0.65 \%$ ) are so low (ranging between 541.5 and $20,354 \mathrm{mg} \mathrm{kg}^{-1}$ or $0.05-2.03 \%$ ), so the decision was taken not to normalise the datasets for this assessment.

The principles of Nicolaus et al. (2015), (2016) and (2017) were followed by using a Risk Characterisation Ratio (RCR) to investigate if concentrations measured are likely to pose a toxicological threat. In summary, the RCR is the ratio between the Measured Environmental Concentration (MEC) and the AC. If the RCR is above 1, then the determinant failed the contaminant specific AC, which then provides environmental managers with an indication that sediment quality in relation to metal contamination may be poor for that location. The RCR also provided a tool to rank and compare the metal concentrations with one another. The higher the RCR for a specific metal is, the greater the potential impact to the marine environment is. 
Whilst the status assessment provides a considered judgment of the current risk posed by metal contamination, it is also important to analyse the direction of any detectable trend to better understand if contaminant concentrations are increasing or decreasing over time. To assess this, a trend assessment was carried out to determine if the contaminant concentrations have improved or deteriorated over the monitoring time series. The same trend assessment methods as described by Nicolaus et al. (2017) were followed by using a generalised additive model (GAM; Wood, 2006) for stations where samples were available in at least five separate years for a specific contaminant at a specific station. The GAM models were fitted using the function 'gam' in the R package 'mgcv'. If only 4 years of data were available, then a linear model was used. No trend assessment was carried out if 3 years or less data were sampled. The GAM analyses incorporate temporal variation over time and are more flexible than linear regression. The gam() function allows us to compare the fitted model against a null hypothesis of 'no trend': the null hypothesis can be rejected, if the $p$-value is $\leq 0.05$. Figure 2 gives an example for the variation in $\mathrm{Cd}$ concentrations over time and the fitted GAM for the station 'Dam' (station number 13). The $p$-value for this example was $<0.05$ which allowed us to reject the null hypothesis of no trend. To judge the direction of the trend, we examined the direction of the trend at the end of the series - which was downwards in this case. This procedure was followed for all determinants at the different stations where a GAM was fitted. All trend assessment figures can be found in the supplementary section under Figure S1.

OSPAR Background Assessment Concentration (BACs; OSPAR, 2008), United States Environmental Protection Agency Effects Range Low (ES EPA ERL; Long \& MacDonald, 1998), US EPA Effects Range Median (ERM; Long \& MacDonald, 1998), Canadian Interim Sediment Quality Guidelines (ISQG; Canadian Council of Ministers of the Environment, 2001) and Probable Effect Levels (PEL; Canadian Council of Ministers of the Environment, 2001); proposed background concentrations according to Al-Abdali et al. (1996) are $1.2-2 \mathrm{mg} \mathrm{kg}^{-1}$ for $\mathrm{Cd}$, $15-30 \mathrm{mg} \mathrm{kg}^{-1}$ for $\mathrm{Cu}$ and $\mathrm{Pb}, 70-80 \mathrm{mg} \mathrm{kg}^{-1}$ for $\mathrm{Ni}$ and $30-60 \mathrm{mg} \mathrm{kg}^{-1}$ for $\mathrm{Zn}$.

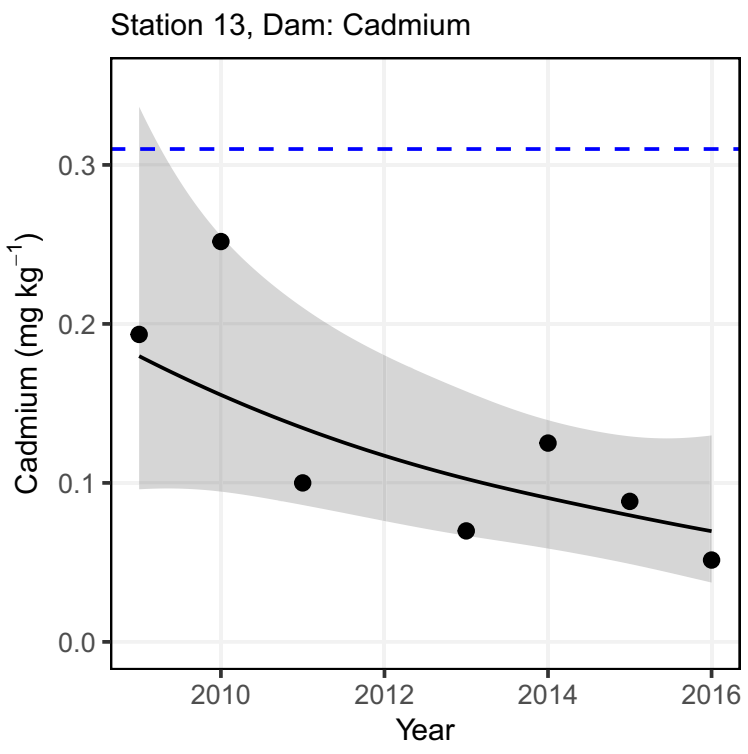

Fig. 2 Variation in cadmium concentrations $\left(\mathrm{mg} \mathrm{kg}^{-1}\right)$ over time and the fitted GAM model. Also shown is the $95 \%$ confidence interval for the fitted GAM model. Blue-dotted line-lowest available assessment criteria for reference (For interpretation of the references to colour in this figure legend, the reader is referred to the web version of this article.)

\section{Results and discussion}

A summary of the maximum measured environmental concentration $\left(\mathrm{MEC}_{\max }\right)$ for a specific metal at a specific station in a specific year and the associated RCR value in relation to the highest and lowest assessment criteria (Table 2) is presented in Table 3. The majority of $\mathrm{MEC}_{\max }$ values recorded were from historic samples (2008-2012) with only the $\mathrm{MEC}_{\max }$ for $\mathrm{Cu}$ recorded in the last 3 years (2019). Background and summary results, including the mean, minimum and maximum concentrations of all determinants at a specific station including the trend assessment, can be found in Table S4 of the supplementary section. The detailed RCRs for each determinant at each station for each sampled year can be seen in Table S5. Tables S5 and S6 also provide information on the measured environmental concentration for each station in each sampled year.

As an example of the risk assessments undertaken, the $\mathrm{MEC}_{\max }$ for $\mathrm{Cr}$ and $\mathrm{Cu}$ were 528 and $280 \mathrm{mg} \mathrm{kg}^{-1}$, respectively (Table 3 ). To assess these concentrations, 
Table 3 Maximum Measured Environmental Concentration (MEC) values recorded and their associated RCR collected in a specific year at a specific site followed by the overall occurrence (\%) of RCRs taking all collected samples into consideration since 2007

\begin{tabular}{|c|c|c|c|c|c|c|c|c|}
\hline Contaminant & $\operatorname{MEC}_{\max }\left(\mathrm{mg} \mathrm{kg}^{-1}\right)$ & Highest RCR & Lowest RCR & Station & Sample year & $\begin{array}{l}\% \text { above } \\
\text { lowest } \\
\text { AC }\end{array}$ & $\begin{array}{l}\% \text { above } \\
\text { highest } \\
\mathrm{AC}\end{array}$ & $N$ \\
\hline $\mathrm{Al}$ & 20,400 & NA & NA & Gasar (20) & 2009 & NA & NA & 240 \\
\hline $\mathrm{Cd}$ & 0.317 & $0.08(\mathrm{ERM})$ & 1.02 (BAC) & Mashtan (2) & 2008 & 0.77 & 0.00 & 259 \\
\hline $\mathrm{Cr}$ & 528 & 1.43 (ERM) & 10.1 (ISQG) & Ya'suf (22) & 2008 & 19.63 & 2.22 & 270 \\
\hline $\mathrm{Cu}$ & 280 & 1.04 (ERM) & 14.95 (ISQG) & Shtaya (24) & 2019 & 25.08 & 0.72 & 279 \\
\hline $\mathrm{Fe}$ & 24,100 & NA & NA & Suhain (10) & 2009 & NA & NA & 240 \\
\hline $\mathrm{Mn}$ & 290 & NA & NA & Ya'suf (22) & 2008 & NA & NA & 279 \\
\hline $\mathrm{Ni}$ & 92.6 & $1.79(\mathrm{ERM})$ & 4.43(ERL) & Refinery area (8) & 2012 & 7.14 & 1.88 & 266 \\
\hline $\mathrm{Pb}$ & 213 & 0.98 (ERM) & 7.05 (ISQG) & Refinery area (8) & 2009 & 6.45 & 0.00 & 279 \\
\hline $\mathrm{Zn}$ & 92.6 & 0.23 (ERM) & $0.76(\mathrm{BAC})$ & Refinery area (8) & 2012 & NA & NA & 269 \\
\hline
\end{tabular}

MEC Measured Environmental Concentration, BAC Background Assessment Concentrations, ERL Effect Range Low, ERM Effect Range Median, ISQG Canadian Interim Sediment Quality Guidelines, RCR Risk Characterisation Ratio for either OSPAR BAC, ISQG, ERL or ERM, $A C$ Assessment Criteria, $N$ number of samples

they were compared to the lowest $\mathrm{AC}$, which indicated that the $\mathrm{Cr}$ concentration was 10 times $(\mathrm{RCR}=10.1)$ above the ISQC. Similarly, $\mathrm{Cu}$ was almost 15 times $(\mathrm{RCR}=14.95)$ above the lowest AC (ISQG). Exceeding the lowest $\mathrm{AC}$ highlights that there is a potential toxicological risk to exposed marine organisms and confidence around this result increases as other, higher AC are breached. Therefore, the MECs were also compared to these AC. Table 3 highlights that individual $\mathrm{Cr}, \mathrm{Cu}$ and $\mathrm{Ni}$ concentration had a RCR above 1 in these instances, suggesting that organisms at these stations may be at risk due to elevated pollution levels. Looking at the dates when these samples were collected, it becomes apparent that these MECs were from historic samples, apart from $\mathrm{Cu}$, which was only measured in 2019 at station Shtaya (station number 24). As such the data highlights the importance on long-term data collection, which allows environmental managers to establish if such values are outliers or are indicative of new pollution sources within a site. Table 3 also shows the occurrences (\%) of the various metals that breached the lowest and highest AC. As an example, $25 \%$ of all $\mathrm{Cu}$ samples and almost $20 \%$ of all $\mathrm{Cr}$ samples breached the lowest $\mathrm{AC}$, whilst less than $1 \%$ of $\mathrm{Cd}$ samples exceeded the lowest $\mathrm{AC}$, indicating that $\mathrm{Cd}$ contamination is not a problem in Bahrain marine waters. Some attention should be given to $\mathrm{Cr}$ and $\mathrm{Ni}$ as these two metals had historic exceedances of around $2 \%$ across all collected samples, when compared to the highest AC (Table 3).
To establish if the historic exceedances are still an issue in the present time, an overview is presented in Table, highlighting the status of a metal in the last sampled year and the trend assessment observed at a specific station. It can be seen from that, that $\mathrm{Cr}(2$ out of 29 sites), $\mathrm{Cu}$ (1 out of 29 sites) and $\mathrm{Ni}$ ( 1 out of 29 sites) still measured concentrations in the last sampled year above the highest AC at a small number of locations (Table 4). Revisiting the above-mentioned $\mathrm{Cu}$ concentration sampled in 2019 at Shtaya (station number 24), which exceeded the highest AC (ERM) in this year, it can be seen that the $\mathrm{Cu}$ concentration has decreased (downward arrow in Table 4), but still exceeded the ERL AC in 2020.

Whilst the status assessment provides valuable information about the current concentrations in relation to the $\mathrm{AC}$, a status assessment gives an indication if concentrations in recent years are decreasing or increasing. In total, 59 significant trends were observed for the various determinants at the 29 stations (Tables 4 and S4). Of these, 23 were significantly upwards whilst 36 were significantly downwards. The most significant upward trends were observed for $\mathrm{Zn}$ and $\mathrm{Mn}$ (7 and 4 significant upward trends, respectively). The most significant downward trends were observed for $\mathrm{Al}, \mathrm{Zn}$ and $\mathrm{Ni}$ (9, 6 and 6 significant downward trends, respectively). Station 8 (Refinery Area) is the only station where three metals $(\mathrm{Cd}, \mathrm{Pb}$ and $\mathrm{Zn})$ showed significant upward trends. Stations Jetty 3 (station number 28), Gasar (station 
Table 4 Summary results ofstatus and trend assessment for trace elements collected in Bahrain sediments

\begin{tabular}{|c|c|c|c|c|c|c|c|c|c|c|}
\hline Station Number and Name & $\mathrm{Al}$ & $\mathrm{Cd}$ & $\mathrm{Cr}$ & $\mathrm{Cu}$ & $\mathrm{Fe}$ & $\mathrm{Mn}$ & $\mathrm{Ni}$ & $\mathrm{Pb}$ & $\mathrm{Zn}$ & $\begin{array}{l}\text { Last sampled } \\
\text { year }\end{array}$ \\
\hline 1 Noon & $0.01 \downarrow$ & $<0.01 \downarrow$ & $0.06 \pi$ & 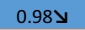 & $0.47 \pi$ & $0.99 \pi$ & $0.11 y$ & $0.87 \pi$ & $0.01 \downarrow$ & 2016 \\
\hline 2 Mashtan & $0.09 \mathrm{y}$ & $0.01 \downarrow$ & $0.59 * y$ & $<0.01 \uparrow$ & $0.42 У$ & $0.12 y$ & $0.01 \downarrow$ & $0.76 \pi$ & $0.02 \uparrow$ & 2020 \\
\hline 3 Jabari & $0.02 \downarrow$ & لע & $0.18 \mathrm{y}$ & $0.23 \pi$ & $0.05 \pi$ & $0.03 \downarrow$ & $0.44 \pi$ & $0.30 y$ & $0.30 \pi$ & 2016 \\
\hline 4 Tugailib & $<0.01 \downarrow$ & $0.22 \pi$ & $0.16 \pi$ & $0.53 \pi$ & 0.34 & $0.33 \pi$ & $0.82 \pi$ & $0.18 \pi$ & $0.21 \mathrm{y}$ & 2015 \\
\hline 5 Ghumais & $0.02 \downarrow$ & $<0.01 \uparrow$ & لا & $0.76 \pi$ & 0.33 & $0.71 \pi$ & 0.19 ل & 0.31 ע & $0.09 \pi$ & 2020 \\
\hline 6 Askar & $<0.01 \uparrow$ & $0.05 y$ & $0.21 y$ & $0.82 \searrow$ & 0.31 ע & $0.10 y$ & $0.81 \pi$ & $<0.01 \downarrow$ & $0.10 y$ & 2020 \\
\hline 7 Msoor & $0.07 \pi$ & $0.21 \pi$ & $0.41 \pi$ & $0.15 \pi$ & $0.34 \pi$ & 0.75 لע & $0.46 \pi$ & لا 0.54 & $0.24 \pi$ & 2016 \\
\hline 8 Refinery Area & $<0.01 \downarrow$ & $0.03 \uparrow$ & لע 0.99 & $0.34 \pi$ & ע 0.10 & $0.85 \pi$ & $0.28 \mathrm{y}$ & $0.04 \uparrow$ & $<0.01 \uparrow$ & 2020 \\
\hline 9 Gaha & $0.13 y$ & لا 0.05 & $0.04 \uparrow$ & $0.36 \pi$ & $0.75 \pi$ & $<0.01 \downarrow$ & $0.19 y$ & $0.76 \pi$ & 0.07 ע & 2016 \\
\hline 10 Suhain & $0.01 \downarrow$ & $0.09 \mathrm{y}$ & $<0.01 \uparrow$ & $0.07 \pi$ & $0.16 y$ & $0.13 y$ & $0.07 y$ & $0.04 \uparrow$ & $0.02 \downarrow$ & $2016 ; 2014 \mathrm{Ni}$ \\
\hline 11 Duwaimil & NA & NA & NA & NA & NA & NA & NA & NA & NA & 2015 \\
\hline 12 Gazara & $0.04 \downarrow$ & $0.37 \pi$ & 0.13 & 0.91 ע & $0.34 \pi$ & $0.19 \pi$ & 0.55 & $<1.00 y$ & $0.28 \mathrm{y}$ & 2020 \\
\hline 13 Dam & $0.15 \pi$ & $0.04 \downarrow$ & $0.07 \pi$ & 0.09 ע & $0.25 \pi$ & $0.20 \mathrm{y}$ & $<1 \pi$ & 0.37 ע & $0.9 y$ & 2016 \\
\hline 14 Jaradah & 0.11 ע & $0.80 y$ & $<0.01 \downarrow$ & $0.23 y$ & $0.32 \pi$ & $0.26 y$ & 0.07 ע & עy 0.47 & $0.03 \uparrow$ & 2020 \\
\hline 15 Jetty 1 & $0.02 \uparrow$ & $0.79 \pi$ & $0.72 \pi$ & $0.52 \pi$ & $0.58 \mathrm{y}$ & $0.17 \mathrm{y}$ & $0.13 \pi$ & $0.21 \pi$ & $0.85 \pi$ & 2014 \\
\hline 16 Al-Jarim & $0.21 \mathrm{y}$ & 0.68 & $<0.01 \downarrow$ & 0.34 & $0.03 \downarrow$ & $0.01 \uparrow$ & $<0.01 \downarrow$ & $0.51 \pi$ & 0.99 & 2020 \\
\hline 17 Khorfasht & $0.08 \pi$ & 0.08 & $0.09 \pi$ & $<0.01 \downarrow$ & 0.29 & $<0.05 \uparrow$ & $0.01 \downarrow$ & $0.10 \pi$ & $<0.01 \downarrow$ & 2016 \\
\hline 18 Murwada & 0.31 ע & 0.74 & لע 0.16 & $<0.01 \uparrow$ & $0.84 \pi$ & 0.07 ע & $0.96 \pi$ & $0.02 \downarrow$ & $<0.01 \uparrow$ & 2020 \\
\hline 19 Bartafi & $0.02 \downarrow$ & $0.34 \pi$ & $0.27 \pi$ & $0.08 \pi$ & $0.76 y$ & $<1 \searrow$ & $<0.01 \downarrow$ & $0.55 \pi$ & $0.23 y$ & 2016 \\
\hline 20 Gasar & $0.07 \pi$ & $0.07 \pi$ & $<0.01 \uparrow$ & $0.06 \pi$ & $0.40 \pi$ & $0.03 \downarrow$ & $<0.01 \downarrow$ & $0.13 \pi$ & $0.03 \downarrow$ & 2016 \\
\hline 21 Umm Al-Na'asan & $0.02 \downarrow$ & $0.63 y$ & $0.06 y$ & 0.83 & $0.29 \pi$ & $0.13 \pi$ & $0.23 y$ & $0.68 \pi$ & $<0.01 \uparrow$ & 2020 \\
\hline 22 Ya'suf & $0.08 \mathrm{y}$ & لע & 0.61 ل & 0.11 ע & 0.22 ע & 0.98 ل & $<0.01 \downarrow$ & 0.43 & $<0.01 \uparrow$ & 2020 \\
\hline 23 Al-Jasra & 0.17 ע & $0.10 y$ & 0.35 & $0.32 * * \pi$ & 0.2 ע & $0.04 \uparrow$ & 0.13 & $0.27 \pi$ & $<0.05 \uparrow$ & 2020 \\
\hline 24 Shtaya & ע 0.89 & $0.05 \pi$ & $0.02 \downarrow$ & ע 0.059 & $0.09 y$ & $0.03 \uparrow$ & $0.95 \pi$ & $0.51 \searrow$ & $0.03 \downarrow$ & 2020 \\
\hline 25 Bulthama & NA & NA & NA & NA & NA & NA & NA & NA & NA & 2015 \\
\hline 26 West Jarim & NA & NA & NA & NA & NA & NA & NA & NA & NA & 2018 \\
\hline 27 Jetty 2 & NA & NA & NA & NA & NA & NA & NA & NA & NA & 2015 \\
\hline 28 Jetty 3 & $0.76 \pi$ & $0.04 \downarrow$ & $0.01 \downarrow$ & $0.05 \pi$ & $0.04 \uparrow$ & $0.14 \pi$ & $0.42 \searrow$ & $0.57 \pi$ & $0.04 \downarrow$ & 2020 \\
\hline 29 Wharf Area & $0.31 \pi$ & $0.98 \mathrm{y}$ & $0.88 \pi$ & 0.89 ل & $0.56 \pi$ & $0.50 \pi$ & 0.85 ע & $0.72 \pi$ & $0.36 y$ & 2020 \\
\hline
\end{tabular}

No status assessment possible as no assessment criterium available

below lowest assessment criteria

above lowest assessment criteria but below $2^{\text {nd }}$ lowest

above $2^{\text {nd }}$ lowest assessment criteria but below $3^{\text {rd }}$ lowest

above $3^{\text {rd }}$ lowest assessment criteria but below $2^{\text {nd }}$ highest

above $2^{\text {nd }}$ highest assessment criteria but below highest

The assessment criteria can be seen in Table 2

NA no trend assessment possible as less than 4 years of data

Numbers represent the $p$-values at the $95 \%$ Confidence Interval

${ }^{*} \mathrm{Cr}$ at station 2 failed the ERL in 2019 and 2018

${ }^{* *} \mathrm{Cu}$ at station 23 almost 10-fold higher compared to next highest year, 2019 and 2018 below lowest EAC; For NI; if above ERL then yellow, if above BAC then orange, if above ERM then purple

$\downarrow$ Significant decrease $(p$-value $<0.05)$

$\uparrow$ Significant increase $(p$-value $<0.05)$

$\searrow$ non-significant decrease $(p$-value $>0.05)$

$\nearrow$ non-significant increase ( $p$-value $>0.05$ )

number 20), Khorfasht (station number 17), Al-Jarim (station number 16) and Noon (station number 1) showed the most significant downward trends ( 3 significant downward trends) for one station.

The significant decreases in Ni could be linked to the way crude oil has been extracted over the survey period, as Al-Abdali et al. (1996) highlighted that $\mathrm{Ni}$ is the largest metal constituent of crude oil and naturally occurs in higher concentrations than in nonoil field areas.

Such trend information allows environmental managers to focus their resources and develop a list of priority sites for further monitoring or investigative studies (Abdulla \& Naser, 2021). Going forward, it would be advisable to re-sample stations Noon and Suhain, as these were last sampled in 2016 and displayed 
exceedances against the highest $\mathrm{AC}$ (ERM) for $\mathrm{Cr}$ in the last sampled year. The trend analysis for these metals at these sites also showed an upward trend and in the case of $\mathrm{Cr}$ at station Suhain, this upward trend was statistically significant ( $p \leq 0.01$; Table 4$)$.

The results of these sites indicate that the ongoing pollution needs continued monitoring. This was addressed in a recent study by Bersuder et al. (2020), who conducted a detailed survey of sediments around the Refinery Area and found that metal contamination was relatively localised around the Refinery Area station and not widespread within that region of coast. More detail on which metal exceeded the relevant AC in the last sampled year and which trends for a specific metal are increasing or decreasing at a specific station can be seen in Table 4 .

Long and MacDonald (1998) suggested that determinants that equal the ERLs or ISQGs or exceed them by a moderate amount (e.g. RCRs of 1.1 to 9.9) should be viewed as chemicals of concern. Chemicals that most frequently exceeded the ERLs or ISQGs and by the greatest amount (e.g. RCR $\geq 10$ ) should be viewed as chemicals of highest priority for further monitoring. Within this study, $\mathrm{Cu}$ sampled at station Al-Jasra (station number 23) would fall within this category. The calculated $\mathrm{Cu} \mathrm{RCR}_{\mathrm{ISQG}}$ and RCR ERL were 14.74 and 8.1, respectively, which would suggest that organisms like filter, suspension and deposit feeders may be at risk to contamination exposure (Bryan \& Langston, 1992). Stations along the south east (one to five) are within the main habitats of dugongs, and according to the results within this study, they are in relatively pristine habitats in relation of metal contamination. However, current data within this area is sparse and it would be advisable to re-initiate sampling at these locations (stations 1, 3 and 4) as they were last sampled between 2015 and 2016 and some determinants like $\mathrm{Cr}, \mathrm{Ni}$ and $\mathrm{Cu}$ highlighted increasing contaminant concentrations and failures for the mid-level assessment criteria.

A common industrial contaminant of concern is $\mathrm{Cd}$, and it is positive that relatively low $\mathrm{Cd}$ concentrations were reported within this study (mean equals $0.11 \mathrm{mg} \mathrm{kg}^{-1}$ ). More than $99 \%$ of all $\mathrm{Cd}$ concentrations were below the BAC. Cd can affect sensitive benthic taxonomic groups like mollusca, polycheata, echinodermata, crustacea and platyhelminthes already at low concentrations $\left(0.0014 \mathrm{mg} \mathrm{kg}^{-1}\right.$ of $\mathrm{Cd}$ affect $5 \%$ of sensitive organisms, whilst over $90 \%$ were affected at $1.0 \mathrm{mg} \mathrm{kg}^{-1}$ according to Leung et al. (2005). The low Cd concentration in the sediment measured in this study and recently confirmed by Bersuder et al. (2020) would indicate that there is a low risk of $\mathrm{Cd}$ accumulating in the food chain and impacting some of the higher trophic fauna (e.g. dugongs and turtles) that graze on the extensive sea grass beds around Bahrain's coast (Burt et al., 2013; Naser, 2015). Al-Abdali et al. (1996) suggested in his study that $\mathrm{Cd}$ (like $\mathrm{Zn}$ and $\mathrm{Mn}$ ) are thought to be natural constituents of the Gulf marine environment and therefore not elements derived from pollutant sources.

Lead, which is seen as a priority hazardous substance within the OSPAR region (OSPAR, 2008), has also shown relatively low concentrations within this study in the last sampled year. Only the Refinery Area (station number 8 ) was above the second highest assessment criteria (PEL), but still below the ERM. Nevertheless, the significant upward trend at this station and at Suhain (station number 10) should be monitored carefully. Bersuder et al. (2020) sampled eight stations around the Refinery Area (station number 8 ) and observed $\mathrm{Pb}$ concentrations varying between 6.85 and $277 \mathrm{mg} \mathrm{kg}^{-1}$ within a $5-\mathrm{km}$ radius in 2019. Such data indicate that spatial variation, even in closely located areas, needs to be considered to ensure that data are truly representative of the location being studied. The observed $\mathrm{Cu}$ concentration of $64.2 \mathrm{mg} \mathrm{kg}^{-1}$ within this study at the Refinery Area (station number 8 ) in 2020 also aligns with the observed concentration by Bersuder et al. (2020) at a co-located site of $70.1 \mathrm{mg} \mathrm{kg}^{-1}$.

\section{Conclusion}

In general, the metal concentrations in sediments observed in this study were satisfactory. Only two $\mathrm{Cr}$, one $\mathrm{Cu}$ and one $\mathrm{Ni}$ concentration in the last sampled year were above the ERM. Nevertheless, the trend analysis highlighted that 23 trends were significantly upwards including determinants that were already above the highest and second highest assessment criteria. The study also showed that the south east (stations two to five) is a relatively pristine area in relation to the observed metal contamination, but resampling would need to be carried out to confirm this. $\mathrm{Cd}$, which is a common industrial 
contaminant of concern, also showed relatively low concentrations within this study. More than $99 \%$ of all $\mathrm{Cd}$ concentrations were below the BAC. Lead has also shown relatively low concentrations within this study in the last sampled year.

Going forward, more area specific surveys should be conducted to investigate local variation further. Bersuder et al. (2020) conducted such an intensive survey around a known impacted site on the Eastern side of Bahrain and similar studies should be conducted at other locations to get a better understanding on local contaminant variations. Additionally, samples should also be analysed for mercury. Taking benthic community samples may also help in identifying biodiversity and abundance hot spots and if these are affected by local contaminant variations. Understanding of the toxicological threat posed by chemical contamination to marine organisms in the Arabian Gulf is an emerging field (Khatir et al., 2020) and further work is required to develop a suite of biological effects tools (e.g. bioassay and biomarkers) that are adapted to local species and can support chemical led monitoring programmes such as described here (Beg et al., 2015; Butler et al., 2020; Smith et al., 2015). Overall, the data presented provides a baseline against which future assessments can be conducted which can support both national and regional efforts to assess marine environmental health (Abdulla \& Naser, 2021; Devlin et al., 2019; ROPME, 2013).

Acknowledgements The authors would like to thank SCE staff, in particular Dr. Mohamed Bin Daina and Eng. Luma AlMahroos, for their continued support and guidance during this collaborative work programme. The authors would like also to acknowledge the work done by SCE laboratory staff, specifically Mr. Hasan Juma, Mrs. May Qais, Dr. Hussain Abdulnabi, Mr. Mohamed Darweesh, Mrs. Fareeda Abdulraheem, Mr. Ali Fardan, Mr. Zuhair Jaffar and Ms. Shaikha Almutawah.

Author contribution E. E. M. Nicolaus initiated and led the study, and drafted the paper initially; A.S. Khamis, K.H. Abdulla, R.P. Harrod, M.J., Devlin and B. Lyons wrote specific sections within the paper and D.L. Maxwell conducted parts of the statistical analyses. All contributed to the manuscript and agree to its submission.

Funding Funding was provided throughout the study period by the UK-Gulf Marine Environment Partnership. The paper was submitted to the Supreme Council for the Environment before submission for approval, which was given.

\section{Declarations}

Conflict of interest The lead author is a British Crown employee, and the paper was written as part of his official duties at Cefas, and therefore, the Crown copyright for the article cannot be assigned. The publishers are, however, authorised to include the article in the journal and in any reprintings or reproduction of EMAS in any form or media, including the sale of reprints, providing it is understood that British Crown copyright and British Crown user rights are reserved.

Open Access This article is licensed under a Creative Commons Attribution 4.0 International License, which permits use, sharing, adaptation, distribution and reproduction in any medium or format, as long as you give appropriate credit to the original author(s) and the source, provide a link to the Creative Commons licence, and indicate if changes were made. The images or other third party material in this article are included in the article's Creative Commons licence, unless indicated otherwise in a credit line to the material. If material is not included in the article's Creative Commons licence and your intended use is not permitted by statutory regulation or exceeds the permitted use, you will need to obtain permission directly from the copyright holder. To view a copy of this licence, visit http://creativecommons.org/licenses/by/4.0/.

\section{References}

Abdulqader, E. A. A. (1999). The role of shallow waters in the life cycle of the Bahrain Penaeid shrimps. Estuarine, Coastal and Shelf Science, 49(1), 115-121. https://doi.org/ 10.1016/S0272-7714(99)80016-X

Abdulla, K. H., Naser, H. A. (2021). Protection of marine environmental quality in the Kingdom of Bahrain. Ocean and Coastal Management, 203, 105520.

Abido, M. S., Abahussain, A. A., \& Abdel Munsif, H. (2011). Status and composition of mangrove plant community in Tubli Bay of Bahrain during the years 2005 and 2010. Arab Gulf Journal of Scientific Research, 29(1), 100-111.

Al-Abdali, F., Massoud, M. S., \& Al-Ghadban, A. N. (1996). Bottom sediments of the Arabian Gulf-III. Trace metal contents as indicators of pollution and implications for the effect and fate of the Kuwait oil slick. Environmental Pollution, 93, 285-301. https://doi.org/10.1016/S0269-7491(96)00046-2

Al-Sarawi, H. A., Jha, A. N., Al-Sarawi, M. A., \& Lyons, B. P. (2015). Historic and contemporary contamination in the marine environment of Kuwait: An overview. Marine Pollution Bulletin, 100, 621-628. https://doi.org/10.1016/j. marpolbul.2015.07.052

Alshemmari, H., Alotaibi, Y., \& Owens, R. (2010). Trace metal concentrations in the surface sediments of Sulaibikhat Bay Kuwait. Kuwait Journal of Science and Engineering, 37(2), 87-110.

Arab Regional Centre for World Heritage, Supreme Council for Environment. (2017). The first regional red list assessment of selected species in the kingdom of Bahrain. Manama, 
Kingdom of Bahrain. http://arcwh.org/filePdfs/BahrainRedList-Report101.pdf

Beg, M. U., Al-Subiai, S. N., Al-Jandal, N., Butt, S. A., Beg, K. R., \& Al-Hussaini, M. (2015). Seasonal effect on biomarkers of exposure to petroleum hydrocarbons in fish from Kuwait's marine area. Marine Pollution Bulletin, 100, 673-680.

Bersuder, P., Smith, A. J., Hynes, C., Warford, L., Barber, J. L., Losada, S., Limpenny, C., Khamis, A. S., Abdulla, K. H., Le Quesne, W. J. F., \& Lyons, B. P. (2020). Baseline survey of marine sediments collected from the Kingdom of Bahrain: PAHs, PCBs, organochlorine pesticides, perfluoroalkyl substances, dioxins, brominated flame retardants and metal contamination. Marine Pollution Bulletin, 161, 111734. https:// doi.org/10.1016/j.marpolbul.2020.111734

Bryan, G. W., \& Langston, W. J. (1992). Bioavailability, accumulation and effects of heavy metals in sediments with special reference to United Kingdom estuaries: A review. Environmental Pollution, 76, 89-131.

Burt, J. A., Al-Khalifa, K., Khalaf, E., AlShuwaikh, B., \& Abdulwahab, A. (2013). The continuing decline of coral reefs in Bahrain. Marine Pollution Bulletin, 72, 357-363. https://doi.org/10.1016/j.marpolbul.2012.08.022

Butler, J. D., Varghese, L., Deb, N., \& Thornhill, B. (2020). Extending international toxicity testing guidance to middle eastern test species. Science of the Total Environment. https://doi.org/10.1016/j.scitotenv.2019.136343

Canadian Council of Ministers of the Environment. (2001). Canadian sediment quality guidelines for the protection of aquatic life: Summary tables. Canadian Council of Ministers of the Environment. http://st-ts.ccme.ca/en/index. html Accessed 9/09/2020

De Mora, S., Tolosa, I., Fowler, S. W., Villeneuve, J.-P., Cassi, C., \& Cattini, C. (2010). Distribution of petroleum hydrocarbons and organochlorinated contaminants in marine biota and coastal sediments from the ROPME Sea Area during 2005. Marine Pollution Bulletin. https://doi.org/10.1016/j. marpolbul.2010.09.021

Devlin, M. J., Lyons, B. P., Bacon, J., Edmonds, N., Tracey, D., Al Zaidan, A. S., Al Ajmi, F., Al-Wazzan, Z. A., Al-Hussain, M. M., Al Khaled, H., \& Le Quesne, W. J. F. (2019). Principles to enable comprehensive national marine ecosystem status assessments from disparate data: The state of the marine environment in Kuwait. Estuarine, Coastal and Shelf Science, 230, 106407. https://doi.org/10.1016/j.ecss.2019.106407

Elghonaimy, I., \& Mohammed, W. E. (2019). Urban heat islands in Bahrain: An urban perspective. Buildings. https://doi.org/10. 3390/buildings904009

Information \& eGovernment Authority. (2021). Bahrain open data portal. http://www.data.gov.bh/en/DataAnalysis Accessed $14 / 01 / 2021$

Khatir, Z., Leitão, A., Lyons, B. P. (2020). The biological effects of chemical contaminants in the Arabian/Persian Gulf: A review. Regional Studies in Marine Science, 33. https://doi. org/10.1016/j.rsma.2019.100930

Leung, K. M. Y., Bjørgesæter, A., Gray, J. S., Li, W. K., Lui, G. C. S., Wang, Y., \& Lam, P. K. S. (2005). Deriving sediment quality guidelines from field-based species sensitivity distributions. Environmental Science and Technology, 39, 5148-5156.

Long, E. R., MacDonald, D. D. (1998). Recommended uses of empirically derived, sediment quality guidelines for marine and estuarine ecosystems. Human and Ecological Risk Assessment. https://doi.org/10.1080/10807039891284956

Lyons, B. P., Barber, J. L., Rumney, H. S., Bolam, T. P. C., Bersuder, P., Law, R. J., Al-Sarawi, H. A. (2015). Baseline survey of marine sediments collected from the State of Kuwait: PAHs, PCBs, brominated flame retardants and metal contamination. Marine Pollution Bulletin, 100. https://doi.org/10.1016/j.marpolbul.2015.08.014

Moore, A. B. M., \& Peirce, R. (2013). Composition of elasmobranch landings in Bahrain. African Journal of Marine Science, 35(4), 593-596. https://doi.org/10.2989/1814232X. 2013.866160

Naser, H. (2011). Human impacts on marine biodiversity: Macrobenthos in Bahrain, Arabian Gulf. The Importance of Biological Interactions in the Study of Biodiversity. https:// doi.org/10.5772/23046.

Naser, H. A. (2015). The role of environmental impact assessment in protecting coastal and marine environments in rapidly developing islands: The case of Bahrain, Arabian Gulf. Ocean and Coastal Management. https://doi.org/10. 1016/j.ocecoaman.2014.12.009

Nicolaus, E. E. M., Law, R. J., Wright, S. R., \& Lyons, B. P. (2015). Spatial and temporal analysis of the risks posed by polycyclic aromatic hydrocarbon, polychlorinated biphenyl and metal contaminants in sediments in UK estuaries and coastal waters. Marine Pollution Bulletin, 95, 469479. https://doi.org/10.1016/j.marpolbul.2015.03.012

Nicolaus, E. E. M., Wright, S. R., Bolam, T. P. C., Barber, J. L., Bignell, J. P., \& Lyons, B. P. (2016). Spatial and temporal analysis of the risks posed by polychlorinated biphenyl and metal contaminants in dab (Limanda limanda) collected from waters around England and Wales. Marine Pollution Bulletin, 112, 399-405.

Nicolaus, E. E. M., Wright, S. R., Barry, J., Bolam, T. P. C., Ghareeb, K., Ghaloom, M., Al-Kanderi, N., Harley, B. F. M., Le Quesne, W. J. F., Devlin, M. J., \& Lyons, B. P. (2017). Spatial and temporal analysis of the risks posed by total petroleum hydrocarbon and trace element contaminants in coastal waters of Kuwait. Marine Pollution Bulletin, 120, 422-427. https:// doi.org/10.1016/j.marpolbul.2017.04.031

Nicolaus, E. E. M., Lyons, B., Miles, A., Robinson, C. D., Webster, L., Fryer, R. (2018). Time trend and status for metals (cadmium, lead and mercury) in sediments. UK Marine Online Assessment Tool. Available at: https://moat.cefas.co.uk/pressures-from-humanactivities/contaminants/metals-in-sediment/

OSPAR. (2008). CEMP Assessment Manual: Co-Ordinated Environmental Monitoring Programme Assessment Manual for Contaminants in Sediment and Biota. OSPAR Publication No 379, OSPAR, London.

OSPAR. (2009). CEMP assessment report:2008/2009 Assessment of trends and concentrations of selected hazardous substances in sediments and biota.

ROPME. (2013). State of the Marine Environment Report2013, ROPME/ GC-16 /1-ii Regional Organization for the Protection of the Marine Environment. Kuwait.

Smith, A. J., McGowan, T., Devlin, M. J., Massoud, M. S., AlEnezi, M., Al-Zaidan, A. S., Al-Sarawi, H. A., \& Lyons, B. P. (2015). Screening for contaminant hotspots in the marine environment of Kuwait using ecotoxicological and chemical screening techniques. Marine Pollution Bulletin. https://doi.org/10.1016/j.marpolbul.2015.08.043 
Tolosa, I., De Mora, S. J., Fowler, S. W., Villeneuve, J. P., Bartocci, J., \& Cattini, C. (2005). Aliphatic and aromatic hydrocarbons in marine biota and coastal sediments from the Gulf and the Gulf of Oman. Marine Pollution Bulletin., 50(12), 1619-1633. https://doi.org/10.1016/j.marpolbul. 2005.06.029

Wood, S. N. (2006). Generalized additive models: An introduction with R. Chapman and Hall.

Zainal, A. J., Al-Burshaid, F., Choudhury, P., \& Abdulla, G. (2009). Coastal development changes and the islands of Bahrain. In R. Loughland \& A. Zainal (Eds.), Marine Atlas of Bahrain (pp. 17-30). Miracle Publishing.
Zainal, K., Al-Sayed, H., Ghanem, E., Butti, E., \& Nasser, H. (2007). Baseline ecological survey of Huwar Islands, The Kingdom of Bahrain. Aquatic Ecosystem Health \& Management, 10(3), 290-300. https://doi.org/10.1080/14634 980701520882

Publisher's Note Springer Nature remains neutral with regard to jurisdictional claims in published maps and institutional affiliations. 